\title{
AN ASSESSMENT OF PROPERTY MAINTENANCE IN HIGH RISE BUILDINGS IN GABORONE (CBD)
}

\author{
Johnson Kampamba ${ }^{1}$, Simon Kachepa ${ }^{2}$, Milidzani Majingo ${ }^{3}$ and Kathata Pearl Babitseng ${ }^{4}$
}

${ }^{1234}$ University of Botswana Faculty of Engineering and Technology, Department of Architecture and Planning

\author{
*Kampambaj@mopipi.ub.bw
}

\begin{abstract}
Purpose: To assess the practice of property maintenance in high rise properties in the Gaborone central business district (CBD). The objectives of this study were to; identify the maintenance practices adopted in high rise building in the CBD area, assess the challenges faced by maintenance personnel in carrying out maintenance works and find out the most preferred maintenance practices in high rise buildings.
\end{abstract}

Methodology: Both primary and secondary sources of data were used. Primary data was collected through the use of questionnaires which were administered to five facility managers of high rise buildings (Masa centre, iTowers, ZambeziTower, Square Tower, and Prime Plaza) and 10o occupants of the buildings. Secondary data was collected from journal articles, published books, conference papers, periodicals and dissertations. Microsoft Excel was used to analyse and present the data.

Findings: Based on literature reviewed, it was revealed that property maintenance is very important in high rise properties and that there are two types of maintenance which are; planned and unplanned maintenance or predictive and emergency maintenance. It was also found out that planned preventative maintenance is the most preferred maintenance activity. Maintenance personnel are often faced with institutional, financial, personnel and equipment and construction and user challenges.

Research limitations/implications: The implication for this study is that if proper maintenance activities are not implemented by maintenance personnel, building occupants will not be satisfied with their occupancy in the building and its life span will ultimately reduce.

Recommendations: Training maintenance personnel should be done in order to ensure that professionals are up-to-date with new technical methods of carrying out maintenance activities effectively. Property owners should be actively involved in construction of high rise buildings so that important information can be documented to eliminate the issue of facilities managers managing properties which they do not have full details about.

Value of the Study: This study has provided a context in which maintenance procedures in high rise buildings can be effectively carried out to improve overall building rating and performance.

Keywords: Maintenance management, maintenance, high rise properties, planned, corrective, emergency and predictive maintenance.

\section{Introduction and background of the study}

High rise buildings represent huge capital outlay for such investments. These building have many building facilities and complex systems (Heating and ventilation system, power system, drainage system) that require extensive maintenance (Au-Yong, Ali, Chua, \& Che-Ani, 2018). It is therefore important that the value and quality of these buildings be maintained throughout the buildings life span. This can only be achieved through effective and proactive property maintenance (Miles \& Syagga, 1987; Zavadskas, Bejder, \& Kaklauskas, 1998; Olanrewaju, 2009; Yahya \& Ibrahim, 2012).

Property maintenance is an effective activity that ensures that deterioration, wear and tear of buildings is reduced
(Chua, Zubbir, Ali, \& Au-Yong, 2018). According to Lateef, Khamidi, \& Idrus (2011) property maintenance encompasses all technical and administrative activities aimed at restoring building elements to their original working condition. Nawi, Salleh, \& Anuar (2014) explain maintenance as an aspect of property management which ensures that all components of a building are in perfect structural, functional and aesthetic condition. It is crucial for building maintenance activities to be undertaken in order to ensure that building elements are operating at an optimum level (Au-Yong, Ali, Chua, \& CheAni, 2018). This therefore enable users or occupants of the building to perform to their maximum potential, without any hindrances due to defects in the building facilities. Most importantly, property maintenance enhances the value and quality of the building thus elongating the overall buildings 
life span (Zawawi \& Kamaruzzaman, 2009).

There are a variety of maintenance strategies that are usually undertaken in high rise buildings. These are categorized into planned and unplanned maintenance (Chan, Lee, \& Burnett, 2003). According to Oseghale (2014) planned maintenance entails forecasting, planning and executing maintenance works in a timely manner. Maintenance works are carried out before failure of items (Irajpour, Fallahian-Najafabadi, \& Karimi, 2014; Muyengwa \& Marowa, 2015). Planned Maintenance is subdivided into planned corrective maintenance and planned preventative maintenance. The advantages of planned maintenance is that it preserves the structure and its amenities at their present condition as maintenance is done before failure of items (Richard, Peter Tse, Ling, \& Fung, 2000). Furthermore, it keeps building elements operating at their optimum level or full ability.

Unplanned maintenance on the other hand is carried out without any predetermined plan. Here conditions of the property as well as the failure of items is certain. Horner, ElHaram, \& Munns (1997) states that the main objective of this strategy is to repair and restore the items back to their original working state. Unplanned maintenance is subdivided into emergency, corrective, predictive and deferred maintenance (Pitt, 1997; Puķīe, Geipele, \& Prof, 2017). According to Chan, Lee, \& Burnett (2003) emergency maintenance carried out to prevent adverse failure in the facility while corrective maintenance is done to restore items back to their original functioning condition. According to Wood (2003) deferred maintenance is the type of maintenance that is withheld from being carried out to a later stage or time. This may be due to unavailability of finances to carry out maintenance works.

However, maintenance personnel are often faced with a variety of challenges when executing maintenance activities. Olanrewaju, Owolabi, \& Owolabi (2015) state that maintenance personnel are often faced with budgetary constraints. Maintenance is usually given the lowest priority in comparison to other departments in a building (Ghazi, 2016). This results in defects in the building components as they are neglected due to budgetary constraints. However, Obadiah (2010) opines that the maintenance departments should be allocated more resources as it is one of the most important departments in an organization. The maintenance department maintain the value and quality of the building and most importantly ensures the safety of the occupants of the building.

Globally, investment in property maintenance is huge. Property maintenance in countries such as America, United Kingdom and China contributes about fifty per cent of the total turnover of the construction industry (Olanrewaju, 2009). However in most buildings within Botswana property maintenance is not given the priority it deserves (Kampamba, Majingo, Kachepa, Nkwae, \& Sello, 2017). This can be ascribed to the fact that maintenance is usually neglected. However, neglecting maintenance has an aggravating effect on building defects (Wordswith \& Lee, 2007). Increased building defects leads to high costs of repair and rectification in the long run (El-Haram \& Horner, 2002; Buys \& Nkado, 2006; Obadiah, 2010; Ghazi, 2016). Maintenance managers in Botswana do not know suitable maintenance strategies for high rise commercial buildings. As a result, it has become increasingly difficult to identify a specific maintenance strategy suitable for high rise buildings.

The study therefore focused on making an in-depth analysis of the maintenance practices in high rise buildings in the Gaborone CBD with a view of recommending a suitable strategy that can be utilized by maintenance personnel. The findings of this study would pave way for formulation of appropriate strategies to assist facility and maintenance managers in adopting effective practices that would help them to efficiently execute maintenance works. Furthermore, the study also addresses the challenges faced by maintenance personnel when executing maintenance works in high rise buildings. The objectives of the study were:

1. To identify the maintenance practises carried out in high rise buildings in Botswana.

2. To determine the importance of maintenance record keeping in high rise buildings

3. To assess the challenges faced by facility and maintenance in executing maintenance works in high rise buildings.

4. To determine the budgets and policies attached to maintenance of the high rise buildings.

5. To find out which system of maintenance is mostly preferred between the conventional and e-maintenance.

This study is critically important as it paves way for formulation of policies and recommendations that could be adopted by facility managers to enhance maintenance performance in high rise buildings. In addition, it provides solutions to the challenges that are faced by maintenance managers when implementing maintenance works. The buildings in the Gaborone CBD are still new and proper maintenance procedures need to be carried out in order to maintain the value and quality of the building.

\section{Methodology}

Gaborone is the capital city of Botswana. It has transformed and evolved over the years into an economic hub. It comprises complex infrastructure, shopping malls, hotels, schools and clinics. The numerous economic activities that occur in the city have resulted in mushrooming of high rise buildings in the city. The new Gaborone Central Business District (CBD) 
comprises many high rise buildings, which have been the subject of this study. These buildings include iTowers, Masa Centre, Zambezi Tower, Square Tower and Prime Plaza. The Gaborone CBD was chosen as the study area as it represents major developments in as far as high rise buildings are concerned. It was therefore of prime interest to investigate how maintenance activities are carried out in these high rise buildings.

A quantitative approach was adopted in order to achieve the objectives of this study. Best and Khan (2006) mention that the quantitative approach is useful in investigating a particular phenomenon. It is used to answer questions on relationships within measurable variables with the intention to explain, predict and control a phenomena (Leedy, 1993; Creswell, 1994; Bryman \& Bell, 2007). This approach will therefore be useful to gain insight on how maintenance activities are carried out by facility managers and maintenance personnel in high rise buildings in Botswana.

Questionnaires were administered to facility managers or maintenance personnel of the five (5) chosen high rise buildings in the Gaborone CBD. Facility managers and maintenance personnel are responsible for regular upkeep and functioning of all building elements. Maintenance managers were asked on information pertaining to the building background, maintenance services provided, systems used as well as problems and challenges that are faced by facilities managers when executing maintenance works in high rise buildings.
Questionnaires were also administered to the occupants of the mentioned high rise buildings. Occupants are tenants, employees, cleaners and security personnel who utilize the building to carry out their work activities. The questions required information regarding awareness of maintenance practices by occupants, time taken to response to maintenance requests and occupants satisfaction with maintenance services. The questions in the questionnaires ensured that data relating to each objective was collected. Table 1 below shows the variables and the measurement scales that were adopted in measuring the variables from each objective.

A five point Likert scale rating system was utilized to rate the responses from the respondents. The Likert scale ranged from strongly disagree to strongly agree. A total of 100 questionnaires were issued out to occupants of the buildings. Another set of questionnaires was issued to 5 facility managers and maintenance personnel of the high rise buildings in the CBD. Simple random sampling was used to select the sample size for the building occupants. Kumar (2014) explains that this method ensures that every member of the population has an equal chance of being selected to be part of the sample, thus ensuring that there is high generalizability. Purposive sampling was used to select the sample for facility managers and maintenance personnel.

Primary and secondary sources of data were used to collect data for this study. Primary data was collected from open and close ended questions that were administered to

Table 1: Variables and indicators for the study

\begin{tabular}{|c|c|c|c|}
\hline OBJECTIVES OF THE STUDY & VARIABLES & INDICATORS & SCALE \\
\hline $\begin{array}{l}\text { To identify the practices of maintenance in } \\
\text { the high rise building in Gaborone. }\end{array}$ & $\begin{array}{l}\text { Mainte nance } \\
\text { practices }\end{array}$ & $\begin{array}{l}\text { The types of maintenance practices used in } \\
\text { buildings } \\
\text { The advantages and disadvantages }\end{array}$ & $\begin{array}{l}\text { Interval } \\
\text { scale }\end{array}$ \\
\hline $\begin{array}{l}\text { To determine the importance of main- } \\
\text { tenance record keeping in high rise } \\
\text { buildings }\end{array}$ & Record keeping & $\begin{array}{l}\text { How many companies do keep records manual- } \\
\text { ly and computerized. }\end{array}$ & $\begin{array}{l}\text { Interval } \\
\text { scale }\end{array}$ \\
\hline $\begin{array}{l}\text { To assess the challenges that are faced by } \\
\text { facilities managers in maintaining high rise } \\
\text { buildings. }\end{array}$ & $\begin{array}{l}\text { Mainten ance } \\
\text { challenges } \\
\text { Maintenance } \\
\text { strategies }\end{array}$ & $\begin{array}{l}\text { The extent of challenges encountered by facili- } \\
\text { ties managers } \\
\text { The criteria used to curb the challenges and } \\
\text { make solutions }\end{array}$ & $\begin{array}{l}\text { Interva } 1 \\
\text { scale }\end{array}$ \\
\hline $\begin{array}{l}\text { To determine the budgets and policies } \\
\text { attached to maintenance of the buildings. }\end{array}$ & $\begin{array}{l}\text { Mainte nance } \\
\text { budget } \\
\text { Maintenance } \\
\text { policies frame- } \\
\text { work }\end{array}$ & $\begin{array}{l}\text { The approaches that companies use to make } \\
\text { maintenance budget } \\
\text { Standards used to formulate maintenance } \\
\text { policies }\end{array}$ & $\begin{array}{l}\text { Interva } 1 \\
\text { scale }\end{array}$ \\
\hline $\begin{array}{l}\text { To find out which system of maintenance is } \\
\text { mostly preferred between the conventional } \\
\text { and e-maintenance. }\end{array}$ & $\begin{array}{l}\text { E-maintenance } \\
\text { model } \\
\text { CMMS } \\
\text { framework }\end{array}$ & $\begin{array}{l}\text { Gap analysis between e-maintenance and con- } \\
\text { ventional maintenance system } \\
\text { The extent of usage of e-maintenance system }\end{array}$ & $\begin{array}{l}\text { Ordin a } 1 \\
\text { Scale }\end{array}$ \\
\hline
\end{tabular}


facility managers and occupants of the buildings. According to Leedy \& Ormrod (2001) open ended questionnaires urge the respondents to express their own sentiments by giving out answers using their own words. This would help the researcher to gain additional insightful information regarding maintenance practices in high rise buildings that would have been otherwise not been captured in close ended questionnaires. Close ended questionnaires on the other hand give the respondents choices to select the answer. Secondary data was collected from books, journal articles, conference papers and published dissertations. These secondary sources were obtained through the use of internet and online databases such as Research Gate, Academia and Emerald-Insight. Data collected was subsequently analysed using Microsoft Excel and presented through the use of graphs and tables.

\section{Results and discussion of findings}

This chapter discusses and analyses the data gathered intended to attain the objectives of this study. It explains the background information of respondents, factors influencing properties/ facilities maintenance management, factors contributing to high cost of maintenance and strategies for improving commercial building maintenance management.

A total number of 100 questionnaires were distributed to the occupants of the buildings in the Gaborone CBD. Only 40 questionnaires were not completed by the respondents therefore resulting in a $60 \%$ response rate. Fincham (2008) mentions that the response rate is acceptable if it falls within 60 per cent to 100 per cent range. Therefore the response rate achieved for this study is acceptable. The high response rate obtained for this study was as a result of direct meetings with the respondents and the use of a well-designed questionnaire that was easy to understand and complete. The questionnaires that were not received or not filled in, was due to the fact that some respondents were reluctant to share information, while others were too busy and some were out of town. The response rate indicates that the targeted sample contributed to study. Another set of questionnaires (5) were distributed to facilities managers found in the selected buildings in the CBD. All facilities and maintenance managers completed and returned the questionnaires thus resulting in a $100 \%$ response rate.

\section{Findings and discussion from the building occupants}

A number of questions were formulated in the questionnaire administered to the building occupants. The questions encompassed demographic data, reasons for occupying the building and satisfaction with maintenance activities done in the buildings. The results from the survey are discussed below.

\section{General information on maintenance managers of the buildings}

In terms of demographics, the occupants of the buildings were asked to indicate their gender as well as their age. The survey revealed that majority of the occupants 52 per cent of the respondents were males while 48 per cent of the respondents were females. In terms of age, 37 per cent of the respondents indicated that their age was below 30 while 35 per cent ranged from 31-40 years. The remaining 27 per cent indicated that they were aged between 41-50 years. None of the respondents were over 51 years old. The respondents were further asked to state the type of building they occupy. Majority of the respondents, 45 per cent stated that they occupy the building for office use while 40 per cent occupied the building for retail purposes. This is because most buildings in the CBD have mixed use. Minority of the respondents, 15 per cent occupied the building for hotel use. This can be attributed to the few hotels that are in the CBD.

The respondents were also asked to state the reasons for occupying the buildings. From the survey made, $58 \%$ of the occupants stated that they were motivated by the condition of the building for them to select it for occupation while the remaining 42 per cent occupied the building due to its convenience and location. None of the respondents occupied the building due to lack of alternative accommodation. The occupants were further asked to state whether they know who is responsible for maintenance of the building. From the survey it clearly shows that the occupants of the building have less knowledge on the maintenance management of their buildings. Minority 13 per cent of the occupants indicated that they know who is responsible for the maintenance services and they all assumed that the management of the buildings (Asset Managers, Facilities Managers) were the ones responsible. Majority of occupants, 87 per cent have no idea on who exactly is responsible for maintenance in their building.

\section{Question 1: How often are building maintenance inspections done?}

The survey revealed that, $65 \%$ occupants of the buildings indicated that from their observation, property inspections are done on a monthly basis and this may be a contradiction to what the maintenance personnel might have said. On the other hand, $28 \%$ of the occupants stated that inspections are done on a daily basis as the building usually has small defects like water leakages; door locks repairs, poor drainage system. Only $7 \%$ of the occupants mentioned that inspections are done annually.

\section{Question 2: How long does it take for maintenance requests made by tenants to be responded to?}

Based on the results, majority $57 \%$ of the occupants said that their requests are responded to within 1-3 days as this depends on the fault that has occurred and extension of some days might have been because of certain parts that might be needed to be purchased. Similarly, $42 \%$ showed that it does not take long for maintenance personnel to respond to their request as maintenance works are usually carried out within 24 hours. Lastly, 2\% of occupants indicated that it takes 3-7 working days to respond to queries 
Question 3: What is the level of awareness of maintenance practices used for effective facility maintenance in organizations that are based in high rise buildings?

Most occupants of the buildings, $45 \%$ indicated that they are very aware on the maintenance practices. $40 \%$ of the respondents stated that they are moderately aware of the practices carried out in their buildings in terms of maintenance. The other respondents, $12 \%$ were slightly aware of the maintenance practices adopted in high rise buildings. These respondents are occupants that use the building for commercial purposes, as in retail shops. The respondents hardly encounter any maintenance work performed in their presence. Lastly, 3\% of the respondents are those who are extremely unaware of the maintenance practices.

Question 4: What is the level of satisfaction as far as maintenance is concerned in terms of quality in your building?

Satisfaction level for quality maintenance at CBD buildings is very important for occupants. From the survey the level of satisfaction was $55 \%$ which is above the average, thus concluding that the services of maintenance provided in the buildings to be very good. According to the level of satisfaction most facilities managers use the preventative maintenance as they do all the touch ups of the fabric of the building before tear and wear, the cleaning services as well as the landscape were also satisfactory because the maintenance personnel made sure that all areas in the building were covered as provided in the schedule. Furthermore $34 \%$ of the occupants of the building were not sure as they are really not aware of the maintenance services provided thus they cannot give out any bad or good implication on the quality of maintenance. Only $3 \%$ of the occupants were not very satisfied by the quality of maintenance in their buildings while $8 \%$ were very satisfied by the quality of maintenance.

Findings and discussion from Facilities manager/ maintenance manager

The discussion below entails the results obtained from the survey administered to facilities managers and maintenance personnel of the five buildings in the CBD (Prime plaza, Masa, iTowers, Square mall and Zambezi tower).

In terms of the demographic characteristics of the respondents the survey revealed that most of the respondents hold strategic positions in the workplace. $40 \%$ of the respondents from the building sample are maintenance managers while the other $40 \%$ are facilities managers. Only $20 \%$ hold maintenance executive positions. Maintenance executive includes positions such as maintenance manager, facility manager, property manager or general manager.

Findings addressing objective one
The first objective was mainly to identify the practices of maintenance in the high rise building in Botswana. A variety of questions were formulated to address this objective. The results are discussed below.

Question 1: What type of maintenance do you use in your property?

Planned maintenance is the most preferred type of maintenance practiced in high-rise buildings. This is shown by the results from the survey where, majority $60 \%$ of maintenance personnel indicated that they prefer planned maintenance. The remaining $40 \%$ indicated that they carry out both planned and unplanned maintenance in their property as some defects may force them to act immediately. It was indicated that when planned maintenance is carried out, maintenance personnel usually use the preventative method which is a sub-type of planned maintenance and when they use unplanned maintenance the type that is implemented is the breakdown or emergency maintenance.

Question 2: Is there a procedure that is used in carrying out maintenance work?

Based on the results, it was indicated that most maintenance personnel confirmed that they have a procedure they use to carry out maintenance. Majority before $60 \%$ of the personnel stated that they have the procedure while $40 \%$ showed that they did not have the procedure. The maintenance manager of the Prime Plaza building stated that they have a procedure that they use which is called the Snag R system. In this system, tenants $\log$ in their complaints and the maintenance personnel use the system to attend to the complaints. The system specifies the job to be carried out, time that the job was carried out and also compiles a report on the maintenance works done in the building. The facilities manager of the iTowers and the Zambezi Mall also confirmed that they have a computerized system that they use to alert their building users on the maintenance to be carried out especially when they deal with electrical faults.

\section{Question 3: How do you carry out maintenance works} in your building?

From the survey, the outcomes were that $40 \%$ of the respondents outsource their maintenance works while $10 \%$ use in-house personnel. The remaining $50 \%$ uses both in-house and outsourcing. The reason to why many organizations have shifted from in-house to outsourcing is because outsourcing maintenance always reduces maintenance procurement to a lump sum. However, there is a high level of risk and uncertainty involved with outsourcing maintenance services (Hui \& Tsang, 2004). Most organizations usually use both inhouse and outsource maintenance as it is convenient.

Question 4: How long does it take to respond to maintenance requests from occupiers by the maintenance 


\section{department?}

Based on the results, $100 \%$ of the maintenance personnel showed that their turn-around time to responding to requests is within 24 hours. This is contrary to the results that were obtained from occupants.

\section{Findings addressing objective two}

The second objective was concerned with determining the importance of maintenance in high rise buildings as well as maintenance record keeping. The following questions were formulated to address this objective.

Question 1: Is it important to keep maintenance records in buildings?

All the facilities managers and maintenance managers stated that it is very important to keep records on maintenance activities for future reference.

Question 2: Is record keeping important in property maintenance in organizations?

The results of the survey revealed that majority $80 \%$ of respondents strongly agreed that record keeping is vital in execution of maintenance works. While minority $20 \%$ of the respondents disagreed that record keeping is vital in maintenance of facilities. Record keeping is a systematic and continuous assessment of the progress of a piece of work over time. It is an ongoing process that checks that a programme is 'on track' in terms of achieving its goals. Records are useful in checking whether services, activities, processes, policies and procedures are being implemented correctly, timely and to an appropriate standard.

Question 3: How are maintenance records in your company stored and accessed?

Maintenance managers in many companies indicated that they are still stuck up on manual record keeping. Majority $50 \%$ of the maintenance managers confirmed that their records are not yet computerized. Records are often lost or misplaced when they are kept in manual form. This therefore results in difficulties when executing maintenance works as records may be needed to ascertain the maintenance activities that were done and their progress. On the other hand, 40\% stated that their records were computerised. The remaining 10\% confirmed that they keep their record in both manual and computerized form. These results show that majority of facility managers are lagging behind in adopting e-maintenance despite the complexities associated with maintaining high rise buildings.

Question 4: How often do you analyze the maintenance records to find out the effectiveness of maintenance carried on your building?
Majority of the respondents $80 \%$ make their analysis on a weekly and monthly basis. Only $20 \%$ of the facilities manager rarely analyse the maintenance records. It is believed that analyzing records enables the maintenance personnel to gauge the performance of the building in terms of maintenance. It also provides an opportunity for decisions to be made regarding improving the effectiveness of maintenance.

\section{Findings addressing objective Three:}

The third objective was aimed at assessing the challenges that are faced by maintenance personnel when carrying out maintenance activities. Respondents were required to rank the challenges that are faced by maintenance personnel in executing maintenance works and the strategies that could be utilised to address these challenges. The results are discussed below.

Question 1: What are the challenges faced by the facilities managers and property developers?

From Table 2 below, $100 \%$ of the respondents believed that financial problems are the main challenges that facilities managers encounters the most and ranked first. General personnel and equipment problems were ranked second as majority $80 \%$ of the respondents agree that lack of skilled labour and shortage of equipment to carry out maintenance pose a serious challenge to maintenance personnel. Ghazi (2016) also noted that insufficicent funds for maintenance and lack of skilled personnel are major barriers faced by maintenance personnel. Institutional problems and construction and user generated problems were ranked third. This was shown by $60 \%$ of the respondents agreeing that institutional challenges and general personnel and equipment problems are challenges faced by maintenance personnel when executing maintenance works.

Question 2: What are the strategies for improving maintenance management in commercial properties/ facilities?

Table 3 below shows that majority of respondents $(80 \%)$ agree that design details and availability of adequate funds are important strategies that are necessary for improving maintenance management in high rise buildings, hence being ranked first. Minority of the respondents $(20 \%)$ disagree that this is significant. Majority of the respondents $(60 \%)$ indicated that training of maintenance personnel was very significant for improving maintenance therefore being ranked second. The respondents believe that building maintenance objectives which are the basis for developing maintenance policy, must be considered in relation to organization's objectives. They also agree that prompt response to reported defects improves maintenance management. This is shown by majority of respondents $(60 \%)$ stating that it is a significant strategy while the minority (40\%) disagree. In general, majority of the 
respondents supported most of the strategies to improve on commercial property/facilities maintenance management of commercial buildings. These findings are in line with those of (Kampamba, Majingo, Kachepa, Nkwae, \& Sello, 2017).

\section{Findings addressing objective Four:}

The fourth objective was to determine how the budgets and policies attached to maintenance of the buildings affect maintenance activities. The following questions were included in the survey in order to address the objective.

Question 10: Is there any amount allocated for carrying out the maintenance work?

It was indicated by the respondents that there is actually Table 2: Challenges faced by facilities managers

\begin{tabular}{|c|c|c|c|c|c|c|c|}
\hline Challenges faced by maintenance personnel & $\begin{array}{c}\text { Strongly } \\
\text { disagree } \\
\text { (1) }\end{array}$ & $\begin{array}{c}\text { Disagree } \\
\text { (2) }\end{array}$ & $\begin{array}{c}\text { Neutral } \\
\text { (3) }\end{array}$ & $\begin{array}{c}\text { Agree } \\
\text { (4) }\end{array}$ & $\begin{array}{c}\text { Strongly } \\
\text { agree } \\
\text { (5) }\end{array}$ & $\begin{array}{l}\text { Mean } \\
\text { Score }\end{array}$ & Rank \\
\hline & & & \multicolumn{5}{|c|}{ Frequency and percentage $(n=5)$} \\
\hline $\begin{array}{l}\text { Institutional challenges } \\
\text { (to find out the priority of maintenance in departments } \\
\text { in a building-the availability of resources, the } \\
\text { legislative standards and administrative capacity) }\end{array}$ & - & $\begin{array}{c}2 \\
(40)\end{array}$ & - & $\begin{array}{l}1 \\
(20)\end{array}$ & $\begin{array}{l}2 \\
(40)\end{array}$ & 3.8 & 3 \\
\hline Financial problems & - & - & - & - & $\begin{array}{c}5 \\
(100)\end{array}$ & 5 & 1 \\
\hline General personnel and equipment problems & - & $\begin{array}{l}1 \\
(20)\end{array}$ & - & $\begin{array}{l}1 \\
(20)\end{array}$ & $\begin{array}{l}3 \\
(60)\end{array}$ & 4.2 & 2 \\
\hline Construction and user generated problems & $\begin{array}{c}1 \\
(20)\end{array}$ & - & $\begin{array}{l}1 \\
(20)\end{array}$ & - & $\begin{array}{l}3 \\
(60)\end{array}$ & 3.8 & 3 \\
\hline
\end{tabular}

Source: Field survey

Table 3: Strategies on improving maintenance management

\begin{tabular}{|c|c|c|c|c|c|c|}
\hline Elements & $\begin{array}{c}\text { Very } \\
\text { Significant } \\
(1) \\
\end{array}$ & $\begin{array}{l}\text { Significant } \\
\text { (2) }\end{array}$ & $\begin{array}{c}\text { Somewhat } \\
\text { Significant } \\
\text { (3) }\end{array}$ & $\begin{array}{c}\text { Not Significant } \\
\text { (4) }\end{array}$ & $\begin{array}{l}\text { Mean } \\
\text { Score }\end{array}$ & Ranking \\
\hline & & \multicolumn{5}{|c|}{ Frequency and percentage $(n=5)$} \\
\hline $\begin{array}{l}\text { Building maintenance policy need to be } \\
\text { agreed upon by maintenance personnel } \\
\text { and top management before implementa- } \\
\text { tion. }\end{array}$ & $\begin{array}{c}3 \\
(60)\end{array}$ & $\begin{array}{c}1 \\
(20)\end{array}$ & - & $\begin{array}{c}1 \\
(20)\end{array}$ & 1.8 & $2^{\text {nd }}$ \\
\hline $\begin{array}{l}\text { Building maintenance objectives must be } \\
\text { considered in relation to organisation's } \\
\text { objectives. }\end{array}$ & $\begin{array}{c}2 \\
(40)\end{array}$ & $\begin{array}{c}1 \\
(20)\end{array}$ & $\begin{array}{c}1 \\
(20)\end{array}$ & $\begin{array}{c}1 \\
(20)\end{array}$ & 2.2 & $3^{\text {rd }}$ \\
\hline $\begin{array}{l}\text { Availability of adequate maintenance fund- } \\
\text { ing }\end{array}$ & $\begin{array}{c}4 \\
(80)\end{array}$ & - & - & $\begin{array}{c}1 \\
(20)\end{array}$ & 1.6 & $1^{\text {st }}$ \\
\hline
\end{tabular}




\begin{tabular}{|c|c|c|c|c|c|c|}
\hline Training of maintenance personnel & $\begin{array}{c}1 \\
(20)\end{array}$ & - & $\begin{array}{c}3 \\
(60)\end{array}$ & $\begin{array}{c}1 \\
(20)\end{array}$ & 2.8 & $5^{\text {th }}$ \\
\hline Adherence to design details avoid errors & $\begin{array}{c}4 \\
(80)\end{array}$ & - & - & $\begin{array}{c}1 \\
(20)\end{array}$ & 1.6 & $1^{\text {st }}$ \\
\hline Prompt response to reported defects & $\begin{array}{c}2 \\
(40)\end{array}$ & $\begin{array}{c}1 \\
(20)\end{array}$ & $\begin{array}{c}1 \\
(20)\end{array}$ & $\begin{array}{c}1 \\
(20)\end{array}$ & 2.6 & $4^{\text {th }}$ \\
\hline
\end{tabular}

Source: Field survey

an amount that is allocated just for maintenance works, that is why majority $80 \%$ of the respondents agreed to the statement while $20 \%$ of the respondents indicated that there were not given any amount for their maintenance works.

Question 1: How frequently do you use the following approaches to draw the maintenance budget?

It can be evidently seen from Table 4 below that majority $60 \%$ of the respondents stated that they always use the formula approach in determining their budgets thus being ranked first. $50 \%$ indicated that they use the condition based approach for their budgets. To read This resulted in the approach being ranked second. The conventional approach was ranked the last as $40 \%$ of the respondents showed that they hardly use the approach.
Question 2: Do you have a fixed capital budget, with limited funds for energy efficiency upgrades?

Facilities managers indicated that they do not have a fixed budget as they draw on reserves for cost effective upgrades. Majority $80 \%$ of the respondents answered "no" to the statement while $20 \%$ showed that they have a fixed capital budget.

Question 3: Do you do maintenance planning in your organization?

The respondents indicated that they do not plan their maintenance activities as most of the faults in the buildings are emergencies and need immediate attention. $60 \%$ of the respondents said "no" to the statement while $40 \%$ showed

Table 4: Types of approach to maintenance budget

\begin{tabular}{|c|c|c|c|c|c|c|c|}
\hline Type of budget approaches & $\begin{array}{l}\text { Rarely } \\
\text { (1) }\end{array}$ & $\begin{array}{l}\text { Sometimes } \\
\text { (2) }\end{array}$ & $\begin{array}{l}\text { Never } \\
\text { (3) }\end{array}$ & Often (4) & $\begin{array}{l}\text { Always } \\
\text { (5) }\end{array}$ & $\begin{array}{l}\text { Mean } \\
\text { Score }\end{array}$ & Rank \\
\hline & \multicolumn{5}{|c|}{ Frequency and percentage $(n=5)$} & & \\
\hline $\begin{array}{l}\text { The Conventional Approach } \\
\text { The building maintenance budget is a percentage } \\
\text { of the annual budget. It is based on previous year's } \\
\text { expenditure with minor adjustments }\end{array}$ & - & - & $\begin{array}{l}3 \\
(60)\end{array}$ & 2 & - & 3.4 & $3^{\text {rd }}$ \\
\hline $\begin{array}{l}\text { The Formula Approach } \\
\text { (Derived from some agreed formula } \\
\text { which quantifies needs in terms of cost per unit area, } \\
\text { a percentage of current replacement cost, or some } \\
\text { other factors, to project future needs) }\end{array}$ & - & - & 2 & - & $\begin{array}{l}3 \\
(60)\end{array}$ & 4.2 & $1^{\text {st }}$ \\
\hline $\begin{array}{l}\text { The Condition-based Approach } \\
\text { (Derived from a survey of conditions of the building } \\
\text { to identify needs of maintenance works) }\end{array}$ & - & - & $\begin{array}{l}2.5 \\
(50)\end{array}$ & $\begin{array}{l}2.5 \\
(50)\end{array}$ & & 3.5 & $2^{\text {nd }}$ \\
\hline
\end{tabular}

Source: Field survey 
that they plan their maintenance activities. These results are different from those obtained by Buys \& Nkado (2006) who found out that sound maintenance plans and policies are necessary for effective property maintenance.

Question 4: Have you developed a long term plan in your organization?

Some facilities managers indicated that they are currently developing a long term maintenance plan. majority $60 \%$ of the facilities manager showed that they do not have a long term plan and $20 \%$ indicated that they have a long term plan. Olanrewaju (2009) and Kampamba, Majingo, Kachepa, Nkwae, \& Sello (2017) emphasizes that organizations should have clear and robust plans and policies in order to achieve maintenance performance. Velmurugan \& Dhingra (2015) add that long term plans are important for forecasting major maintenance work. The $20 \%$ that showed that they have a long term indicated that they use preventative maintenance and they update their long term maintenance plan every three to five years. The remaining respondents, $20 \%$ stated that they were currently developing it.

\section{Findings addressing objective Five:}

The last objective was concerned with finding out the type of maintenance system (conventional and e-maintenance) mostly preferred by facility managers.

Question 1. Do you consider using the e-maintenance in your property and how is it effective on your company?

The survey revealed that most facilities managers prefer using e-maintenance especially those that were still stuck in the manual process of carrying out maintenance services. This was shown by the majority $80 \%$ of the respondents stating "yes" to question while just $20 \%$ stated "no". The respondents believe that the e-maintenance system would be effective to their organizations because they will now have easy communication with the building users and it will ultimately improve on the maintenance performance of the buildings. Kans (2009) opines that e-maintenance ensures that there is effective maintenance management in buildings. In addition, high rise buildings have complex components and systems thus necessitating the need for an advanced system. In their study, Buys \& Nkado (2006) found out that majority of the maintenance managers preferred e-maintenance over manual maintenance.

\section{Conclusions and recommendations}

This previous section presented, analyzed and discussed the data that was received from the questionnaires' handed to building occupants and maintenance personnel. The purpose of this section is to give a brief summary of findings, conclusion and recommendations that could be done to ensure high rise buildings in Gaborone, Botswana are properly maintained. In addition, a suggestion of further areas of study that could be embarked on by other academicians is outlined.

\section{Summary of key findings}

The purpose of this study was to investigate maintenance practices in high rise buildings in Gaborone, Botswana. There were five objectives that were posed at the beginning of this study. The results of each objective are summarized below.

\section{To identify the practices of maintenance in the high rise} building in Botswana

The preventative method which is a sub-type of planned maintenance is the maintenance practice that is mostly used in the high rise buildings. Maintenance personnel also use emergency maintenance which is a type of unplanned maintenance.

To determine the importance of maintenance and maintenance record keeping in maintenance planning

Record keeping is essential in maintenance because it is used to track the works done and the appropriate procedures followed when carrying out the maintenance works. Most organization have computerized their records even though some are still stuck in manual recording.

To assess the challenges faced by maintenance personnel in executing maintenance activities

The main challenges that are faced by facility managers in executing maintenance works include financial constraints, unavailability of resources as well as the skilled manpower to conduct and supervise property maintenance activities. Outsourcing may contribute to be one of the challenges, since contractors are the ones responsible for the maintenance works, thus associating the problems to the contractors with their poor management of the maintenance team. Financial constraints and lack of skilled manpower are the other challenges that were noted. However, most of the challenges faced by maintenance personnel arise from poor maintenance planning of high-rise buildings. Therefore most organisations have adopted planned maintenance strategy in order to deal with these challenges.

To determine how the budgets and policies attached to maintenance of the buildings affect maintenance activities

Maintenance is overseen by policies and adopted practices as developed by the maintenance manager or the property developer of the respective building as revealed by the survey. The policy has provisions for the following elements; resource allocation, performance requirements, execution of work, position of maintenance department and administrative activities. Budgets and policies ensure that resources are used adequately when executing maintenance works.

To find out which system of maintenance is mostly preferred between the conventional and e-maintenance 
Maintenance personnel in the CBD are still stuck in the use of conventional maintenance and it is just a few organisations that have started the e-maintenance system even though they still use conventional maintenance system. But the maintenance personnel indicated that the e-maintenance is the most preferred as it easy their work and it is more effective.

\section{Conclusions and implications}

The study has thoroughly addressed the objectives that were posed at the beginning of this study. Secondly, the research has contributed to new knowledge as no study has specifically investigated maintenance practices in high rise buildings in Botswana. The survey results provide a strong foundation for future research exercises aimed towards the successful maintenance of high rise buildings in Botswana. The findings suggest that understanding these factors is extremely important as it ensures that the value and quality of buildings is achieved through effective property maintenance.

\section{Recommendations}

The following recommendations are directed at addressing the issues and challenges recognised during the research process and suggestions are outlined to help improve the maintenance processes in high rise buildings. Below are some recommendations:

Training maintenance personnel. Training empowers maintenance personnel and also improves their professional development. It also ensures that they are up-to-date with new technical methods and systems of carrying out maintenance activities effectively.

- $\quad$ Post occupancy evaluation must be done by facilities and maintenance managers in order to obtain information from building occupants. This information will be used to help improve the way maintenance is carried out in high rise buildings.

- Top management should emphasize on improving their involvement in newly built structures so that the significant information can be documented. This will eliminate the issue of facilities managers managing properties which they do not have full details about as this may lead to them using the corrective maintenance frequently thus increasing the maintenance costs.

- Maintenance managers should start using Computerised Maintenance Management System (CMMS) in high rise buildings. This system helps managers to record and store information about maintenance activities. This helps managers to be able to make decisions regarding maintenance in the buildings.

\section{Further areas of the study}

The study recommends on the areas to be further research as follows: i. Further studies could be done on measurement of maintenance performance levels in high-rise buildings.

ii. The role of e-maintenance in high rise buildings and its implications for the future

\section{References}

1. Adejimi, A. (2005). Poor Building Maintenance in Nigeria: Are Architects Free From Blames? Proceedings of ENHR International Conference on Housing: New Challenges and Innovations in Tomorrow ${ }^{\text {ee }}$ C Cities,. Iceland.

2. Ahmad, R. B. (2006). Maintenance Management and Services (Case Study: PERKESO, Buildings in Peninsular of Malaysia), Unpublished Master's Thesis. University Technology Malaysia.

3. Aliyu, A. A., Ahmad, A., \& Alhaji, M. U. (2015). Application of Facilities Management Practice in High Rise. Bauchi.

4. Au-Yong, C. P., Ali, A., Chua, S., \& Che-Ani, A. (2018). Maintenace Interval towards Different Facilities and Services in High-Rise Housing. Journal of Design and Built Environment, Special Issue(1), 54-61.

5. Bryman, A., \& Bell, E. (2007). Business Research Methods (2nd ed.). Oxford University Press.

6. Buys, F., \& Nkado, R. (2006). A Survey of Maintenance Management System in South African Tertiary Educational Management. Construction Management and Economics, 21(10), 997-1005.

7. Chan, K. T., Lee, R. H., \& Burnett, J. (2003). Maintenance Practices and Energy Performance of Hotel Buildings. Strategic planning for Energy and the Environment, 23(1), 6-28.

8. Chan, K. T., Lee, R., \& Burnett, J. (2001). Maintenance Performance: A case study of Hospitality Engineering Systems. . Facilities 19 (13/14), 494-503.

9. Chua, S. J., Zubbir, N. B., Ali, A. S., \& Au-Yong, C. P. (2018). Maintenance of High-rise Residential Buildings. International Journal of Building Pathology and Adaptation, 36(2), 137-151 .

10. Creswell, J. W. (1994). Research Design: Qualitative \& Quantitative Approaches. . London: Sage Publications.

11. El-Haram, M., \& Horner, M. (2002). Factors Affecting Housing Maintenance Cost. Journal of Quality in Maintenance Engineering, 8(2), 115-123.

12. Ghazi, K. M. (2016). Maintenance Mnagement Practices in 5-star Hotels. Journal of Faculty of Tourism and Hotels, Fayoum University, 10(1/2), 161-191.

13. Horner, R., El-Haram, M., \& Munns, A. (1997). Building Maintenance Strategy: A New Management Approach. Journal of Quality in Maintenance Engineering 3(4), 273-280.

14. Hui, E. Y., \& Tsang, A. H. (2004). Sourcing Strategies of Facilities Management. Journal of Quality in Maintenance Engineering, 10(2), 8592.

15. Irajpour, A., Fallahian-Najafabadi, A., \& Karimi, M. (2014). A Framework to Determine the Effectiveness of Maintenance Strategies Lean Thinking Approach. Mathematical Problems in Engineering, 1-12.

16. Kamaruzzaman, S.-N., Myeda, N. E., \& Pitt, M. (2013). Performance Levels of High-rise Private Office Buildings Maintenance Management in Malaysia. Maintenance and Reliability, 15(2), 111-116.

17. Kampamba, J., Majingo, M., Kachepa, S., Nkwae, B., \& Sello, K. (2017). An Analysis of Maintenance of Government Housing Facilities in Gaborone, Botswana. 15th International Biennial Conference.

18. Kans, M. (2009). The Advancement of Maintenance Information Technology: A Literature Review. Journal of Quality in Maintenance Engineeering. 15(1)6., 5-16. 
19. Kumar, R. (2014). Research methodology: Astep-by-step guide for beginners, 4th edition. . London: Sage publications Pty Ltd.

20. Lateef, O. A., Khamidi, M. F., \& Idrus, A. (2011). Appraisal of Buidling Maintenace Management Practices of Malaysian Universities. Journal of Building Appraisal, 6(3-4), 261-275.

21. Lee, H. .., \& Scott, D. (2008). Identification of main aspects in the management of building maintenance operation processes. Surveyors Times ,Hong Kong Institute of Surveyors, 17(6), $37-41$.

22. Lee, R. D. (1987). Building Maintenance Management. Granada, London: William Collins Sons and Co. Ltd.

23. Lee, Y. H., Hackman, Scott, \& David. (2009). Overview of Maintenance Strategy, Acceptable Maintenance Standard and Resources from a Building Operation Perspective. Journal of Building Appraisal.

24. Leedy, P \& Ormrod (2001). Practical research planning and design. 7th Edition. Merrill Prentice Hall and Sage publications. Upper Saddle River. New Jersey and Thousand Oak, CA.

25. Miles, D., \& Syagga, P. (1987). Building Maintenance: A Management Manual. London.: Intermediate Technology Publications,.

26. Muyengwa, G., \& Marowa, Y. N. (2015). Analyzing Adoption of Maintenance Strategies in Manufactering Companies. International Association for Management and Technology 2015, (pp. 879-903).

27. Nawi, M. N., Salleh, N. A., \& Anuar, H. S. (2014). A Review Study of Maintenance and Management Issues in IBS Commercial Building. International Journal of Computer Informatics \& Technological Engineering, 1(1), 1-5.

28. Obadiah, O. (2010). Maintenance of Petrol Stations; Practices and policies. Unpublished Thesis. Nairobi: University of Nairobi.

29. Olanrewaju, A. L. (2009). Building maintenance management in Malaysia. Journal of Building Appraisal, 4(3), 207-214.

30. Olanrewaju, Owolabi, S. B., \& Owolabi, S. B. (2015). The Challenges of Building Maintenance in Nigeria: A Case Study of Ekiti State. European Journal of Educational and Development Psychology, 3(2), 30-39.
31. Oseghale, G. E. (2014). Impact of Maintenace Strategies on the Performance of Industrial Facilities in Selected Industrial Estates in Lagos State, Nigeria. American Journal of Engineering Research (AJER), 3(8), 171-179.

32. Pitt, T. J. (1997). Data Requirements for the Prioritization of Predictive Building Maintenance. Facilities 15 (3/4), 97-104.

33. Puķīe, I., Geipele, I., \& Prof., D. O. (2017). Different Approaches to Building Management and Maintenance. Procedia Engineering, 172, 905912.

34. Richard, C., Peter Tse, P., Ling, L., \& Fung, F. (2000). Enhancement of Maintenance Management through Benchmarking. Journal of Quality in Maintenance Engineering, 6(4), 224-240.

35. Sekaran, U., \& Bougie, R. ( 2017). Research methods for Business. A Skill Building Approah. International Journal of Informaation Technology and Management.

36. Spedding, A. (1987). Building Maintenance Economics and Management. London: E. \& F. N. Span.

37. Velmurugan, R. S., \& Dhingra, T. (2015). Maintenance Strtegy Selection and its Impact in Maintenannce Function. Intrnational Journal of Operations and Production Manaagment, 35(12), 1662-1661.

38. Wordswith, P., \& Lee., R. (2007). Building Maintenance Management. Oxford, U.K.: Blackwell Publishers,.

39. Yahya, M. R., \& Ibrahim, M. N. (2012). Building Maintenance Achievement in High Rise Commercial Building: A Study in Klang Valley, Malaysia. OIDA International Journal of Sustainable Development, 4(6), $39-46$.

40. Zavadskas, E., Bejder, E., \& Kaklauskas, A. (1998). Raising the Efficiency of the Building Lifetime with Special Emphasis on Maintenance. Facilities 16(11). 334-340. 